\title{
SEC31A Gene
}

National Cancer Institute

\section{Source}

National Cancer Institute. SEC31A Gene. NCI Thesaurus. Code C101475.

This gene plays a role in anterograde transport. 